\title{
Influencing Phenomena of Local Government Budgeting Decisions in Bangladesh
}

\author{
Mohammad Rafiqul Islam Talukdar \\ Correspondence: Mohammad Rafiqul Islam Talukdar, Faculty of Business Administration (FBA), American \\ International University-Bangladesh (AIUB), Dhaka-1229, Bangladesh. The study was conducted while he was at the \\ Graduate School of Public Administration (GSPA), National Institute of Development Administration (NIDA), Serithai \\ Road, Bangkapi, Bangkok -10240, Thailand.
}

Received: August 22, 2019

doi:10.11114/ijlpa.v3i1.4829
Accepted: December 24, 2019

Online Published: April 26, 2020

URL: https://doi.org/10.11114/ijlpa.v3i1.4829

\begin{abstract}
The research on the influencing phenomena at the budgetary process of Local Government Union Councils in Bangladesh is based on a combination of political psychology, applied economics and public management issues (i.e. decentralization, local government finance, and local governance, as well as the budgeting theory and local government budgetary process). The purpose of the research is to explore the critical influencing phenomena and their relative influences on Union Councils' budgeting decisions. The study reveals that the influence of concerned phenomena or issues does not always collide with the budgetary autonomy of Union Councils, but the effects of the influencing issues on their budgeting decisions are evident with varying degrees and dimensions. The study has employed qualitative method with six case studies on criteria based purposively selected Union Councils at Sunamganj District in Bangladesh.
\end{abstract}

Keywords: Bangladesh, budgeting-decision, influence, local government, Union Council

\section{Introduction}

Exploring the critical influencing phenomena at budgeting decisions of local government Union Councils in Bangladesh, requires predominantly consideration of the fact that the local government budgeting becomes a major process of gaining public resources through intergovernmental transfers and by mobilizing local resources, as well as efficient planning and strategic allocation of the resources along with controlling the fiscal management.

Therefore, examining the de jure and de facto influences on budgetary progression of the Union Council/Parishad (UP), the lowest tier of the local government in Bangladesh, entails a combination of political psychology, applied economics and public management issues (i.e. decentralization, local government finance, and local governance, as well as the budgeting theory and local government budgetary process). Considering such skeleton of the study outlook, the research is going to explore the critical phenomena that influence the UP-budgeting process and decisions.

More specifically, the purpose of this research is twofold. First, to explore the nature of the de facto and de jure issues that could influence the UP budgetary process. Analysis of the findings from in-depth interviews and focus group discussions (FGDs) could satisfy this purpose.

Second, to reveal the context specific relative influence of each issue or aspect on UP budgeting decisions through critical analysis of the findings from in-depth interviews and FGDs, and by applying grounded-theory data-analytic principles, for example, 'incident-to-incident' and 'constant-comparison' (Glaser, 1978).

The current round article on budgeting decisions of local government Union Councils includes discussion on the research method, conceptual analysis, research results and contributions, as well as the conclusion.

\section{Research Method}

The research employs here qualitative research method with six case studies on criteria based purposively selected Union Councils/Parishads (UPs) of Sunamganj District/Zila in Bangladesh (see Appendix A). The data collection techniques include 'in-depth interviews' of chairpersons and secretaries of the unit of analysis, 'focus group discussions' with members of UPs, 'document reviews' of UPs, and 'researcher's comprehensive observations'. The unit of analysis is the Union Council, the lowest tier of the local government institutes in Bangladesh (see Appendix B). Data were collected during January-February 2018. 
The study further employs an emergent framework (Baker et. al, 2011). The emergent approach allows here understanding the concerns of research questions from the perspective of the elected representatives, i.e. chairmen and members of UPs, as well as secretaries to the UPs. It is the research participants' perceptions and concerns as they emerge, rather than their voice being refocused.

There are two key research questions of this study.

i. What are the key phenomena that influence the budgeting decision making process of Union Councils in their local governance? What are the de facto and de jure phenomena here?

ii. What are the relative influences of aspects or issues in UP-budgeting process and decisions? Do they collide with the autonomy of Union Councils in their budgeting decisions?

The practical contribution of this study is context specific and thus has circumscribed mostly within the study district, while the theoretical contribution, following the grounded theory building approach and certain assumptions of the context, is subject to generalize both country-wide and globally.

\section{Conceptual Analysis}

The local government planning and budgeting get centrally positioned in the discussion of subnational level of decentralization, especially in its fiscal as well as political decentralization, in relation to autonomy of the localized level of governments.

\subsection{Concept of Local Governance in Relation to Decentralization}

The concept of 'governance' denotes the inter-relationship between the state and society, and/or the government and governed, and the focus of this is more on process and outcomes than on formal institutional arrangement and structure. As such, the concept of 'local governance' is governing at the local level, viewed broadly to include not only the machinery of local government, but also the community at large, as well as the interactions between the former and latter (Talukdar, 2013).

Strengthening local governance means fostering good governance in any modern state as it helps build rights-based approach to development of communities with special focus on social, economic and political welfare of the marginal groups of people in the society of a given state. Central to ensuring good local governance is efficiency, citizenry accountability and effectiveness of local public service delivery and local development, which all together require strengthening the political, administrative and fiscal aspects of local government institutions.

Scholars, donors, and governments around the world are increasingly in agreement with the fact that the strengthening local governments is instrumental in bringing the development dialogues closer to those that matter most in the development process itself - the communities and peripheral people themselves, thus solidification of the local governance to harmonize the results of such dialogues (Talukdar, 2014).

Simply subnational decentralization refers to the 'devolution' that is the increased reliance upon the local government institutions, with some degree of political autonomy (USAID, 2000). Academically, devolution does not necessarily mean democratic decentralization or institutionalization of democracy in local governance, but there is an inclination to equate the two (Oxhorn, 2004). Democratic decentralization goes further than the devolution does in terms of autonomy, responsibility and accountability of the local authority, and participation, opportunity and emancipation of the people. Two interlinked and inevitable components of this latest form of decentralization are structural decentralization and institutional democratization (Talukdar, 2013).

Structural decentralization refers to devolution in the organization and relationship of government units, in relation to one another including a shift of production and provision functions to more localized government units (Hicks and Kaminski, 1995; Rainey, 1997).

Basically, structural decentralization alerts the balance of exercising the power among levels of government favoring localized levels of government; even to some extent this component allows local people's representatives to govern the local government, but values associated with legacy do not always change until it goes with institutional democratization (Talukdar, 2013 and 2014).

Institutional democratization refers to this shift in values, rules, skills, and interactions, favoring transparency, equity, responsiveness, accountability, and other traditional democratic values (Hodgson, 2006; McGill, 1997; OECD, 1996).

Evidence of 'institutional democratization' can be found through functioning monitoring and accountability mechanisms, and by ensuring the efficient integration of citizenry input into public decision-making process (Coston, 1998; Klingner, 1996). 
A fully-fledged democratic decentralization not only creates environment for wider participation and social inclusiveness, as well as for citizens to demand accountability of local authority, but also generates a sense of transparency and accountability of the political system and governance (Talukdar, 2013 and 2014).

It is gratifying to see the fact that researchers are recognizing the decentralization that takes place within a political context, and therefore notions of decentralization evolve differently in each country (Smoke, 2003); yet, the requirements of decentralization set unvaryingly high standards (Dauda,2006).

Although Bangladesh is stepping ahead to the latest form of subnational decentralization - democratic decentralization, there are lots of challenges ahead in this connection, particularly concerning the fiscal and budgetary autonomy of the local government institutes, and so is true in the context of local government Union Councils.

\subsection{Local Governance in Bangladesh}

In response to the decentralization and local governance, globally there are lots of stories for both failures and successes. Evidence from Eckardt (2008) supports that in spite of the extensive strides of the devolution of authority, and sufficient resources placed to the elected local governments, decentralization in Brazil, Colombia and West Bangal has gained little in improving quality service delivery. Grindle (2007), however, identified the fact that local officials were celebrated for the innovations they had introduced in the community governance and the new spaces they had shaped for the civic participation.

In some cases, governments became world famous for such innovations, as did Porto Alegre, Brazil, when it introduced participatory budgeting process. In Mexico, cities such as Monterrey, Leon, and Aguascalientes became well-known models for efficient and responsive governance. In municipalities in Kenya, India, the Philippines, South Africa, and elsewhere, citizens shared information, made decisions about resource allocation, monitored policy implementation, and envisioned improvements that would alter the future of their communities (Grindle, 2007:2).

Furthermore, Talukdar (2013) reveals that Sirajganj in Bangladesh is also noted for the local governance development that is resultant from Sirajganj Local Governance Development Fund Project (SLGDFP). ${ }^{1}$ The experience of Union Councils/Parishads' Governance in Sirajganj had been exercised at Unions all over Bangladesh through the Local Governance Support Project (LGSP), with a special emphasis on the Unions of 6 Districts (Sirajganj, Barguna, Feni, Narshindi, Hobigonj and Sathkira) through the LGSP-LIC. ${ }^{2}$ While the LGSP-LIC succeeded the Union Parishad Governance Project (UPGP), the LGSP succeeded the LGSP-II and LGSP-III.

According to Talukdar (2013), although democratic decentralization can be conducive to poverty reduction through a rights-based approach, for a country like Bangladesh, the key likely challenges here are a marginalized population, and the lack of local resources, material, finance, expertise and competent leadership. These alone, however, are not the crucial factors for the success of decentralization in Bangladesh and elsewhere. The most crucial part entails the changing attitude and behavior, and institutionalizing decentralization with democratic values.

Moreover, the absence of an aggregate local governance policy is a serious governance concern in Bangladesh, which affects effective implementation of decentralization policies and programmes intermittently undertaken from time to time. In fact, democratic decentralization concerning fiscal autonomy and local administrative reforms in Bangladesh have been in midpoint for decades (Ahmed, 2015; Talukdar, 2014).

Importantly the contemporary world is experiencing profound change in the concept of local government, aiming to strengthen the subnational government as a body corporate and to encounter local economic activities in addition to attaining political and social welfare (Talukdar, 2013).

Thus, the 'local government' can be termed as the linchpin of good governance for any modern state, specifically to attain political, economic and social welfare of the marginal groups of people within the state (Falguni, 2009). ${ }^{3}$

\footnotetext{
${ }^{1}$ Sirajganj Local Governance Development Fund Project (SLGDFP), supported by UNDP and UNCDF, had been running successfully from 2000 to 2007 in the 82 Union Parishads of Sirajganj district.

${ }^{2}$ Local Governance Support Project- Learning and Innovation Component (LGSP-LIC), supported by UNDP, UNCDF, EC and Danida, was an innovative project of the Local Government Division of Bangladesh Government. Basically, it was the second-generation pilot project of SLGDFP and the leading as well as innovative component of the Local Governance Support Project (LGSP), which was a full-fledged project of the Local Government Division of Bangladesh Government with the soft loan of WB.
}

${ }^{3}$ http://www.thedailystar.net/news-detail-118255 Retrieved on November 18, 2017. 
The contemporary local government in Bangladesh focuses on how the current paradigm of decentralization can open avenues for the development of democratic local governance. To get the proper outcome of this latest form of decentralization, local government must be responsive to citizen needs and gain the authority, resources and skills needed to be operative and accountable (Talukdar, 2013).

Nonetheless, the constitutional commitment as well as the spirit, as cherished in the constitution of Bangladesh, has never been transformed into reality. Furthermore, the power of the local government, national-local relationships and balance of power, convergence of democratic and fiscal decentralization, as well as functions and functionaries of the local government are neither clearly encompassed in the constitution, nor in laws and practice (Talukdar, 2014). Table-1 shows the local government institutions in Bangladesh at a glance.

Table 1. Local Government Institutions in Bangladesh

\begin{tabular}{|c|c|c|}
\hline Urban Local Government & Rural Local Government & Special Local Government \\
\hline City Corporations (11) & Zilla Parishads (61) & $\begin{array}{lll}\text { Chittagong } & \text { Hill } & \text { Regional } \\
\text { Council (1) } & & \end{array}$ \\
\hline Municipalities (323) & Upazila Parishads (490) & $\begin{array}{l}\text { Chittagong Hill District } \\
\text { Councils (3) }\end{array}$ \\
\hline Cantonment Boards (30) & Union Councils/Parishads (4553) & $\begin{array}{l}\text { Traditional Raja (3) and } \\
\text { Mouza } \\
\text { Headman-Karbari (472) }\end{array}$ \\
\hline
\end{tabular}

\section{Source: Talukdar, 2013}

As shown in Table 1, there are a total of 11 City Corporations, 323 Municipalities (out of which 3 are in the hill area), 61 Zila Parishad/District Councils, 490 Upazila Parishads/Sub-districts (out of which 25 are in the hill area), 4553 Union Parishads (out of which 118 are in the hill area), 1 Hill Regional Council, 3 Hill District Councils, 3 Traditional Raja, and 472 Headman Karbari. Noteworthy is the fact that Cantonment Board is not being considered as the local government unit in a purely academic sense.

Figure-1 below shows the structure of the Union Council as the Local Government Institute (LGI) in Bangladesh.

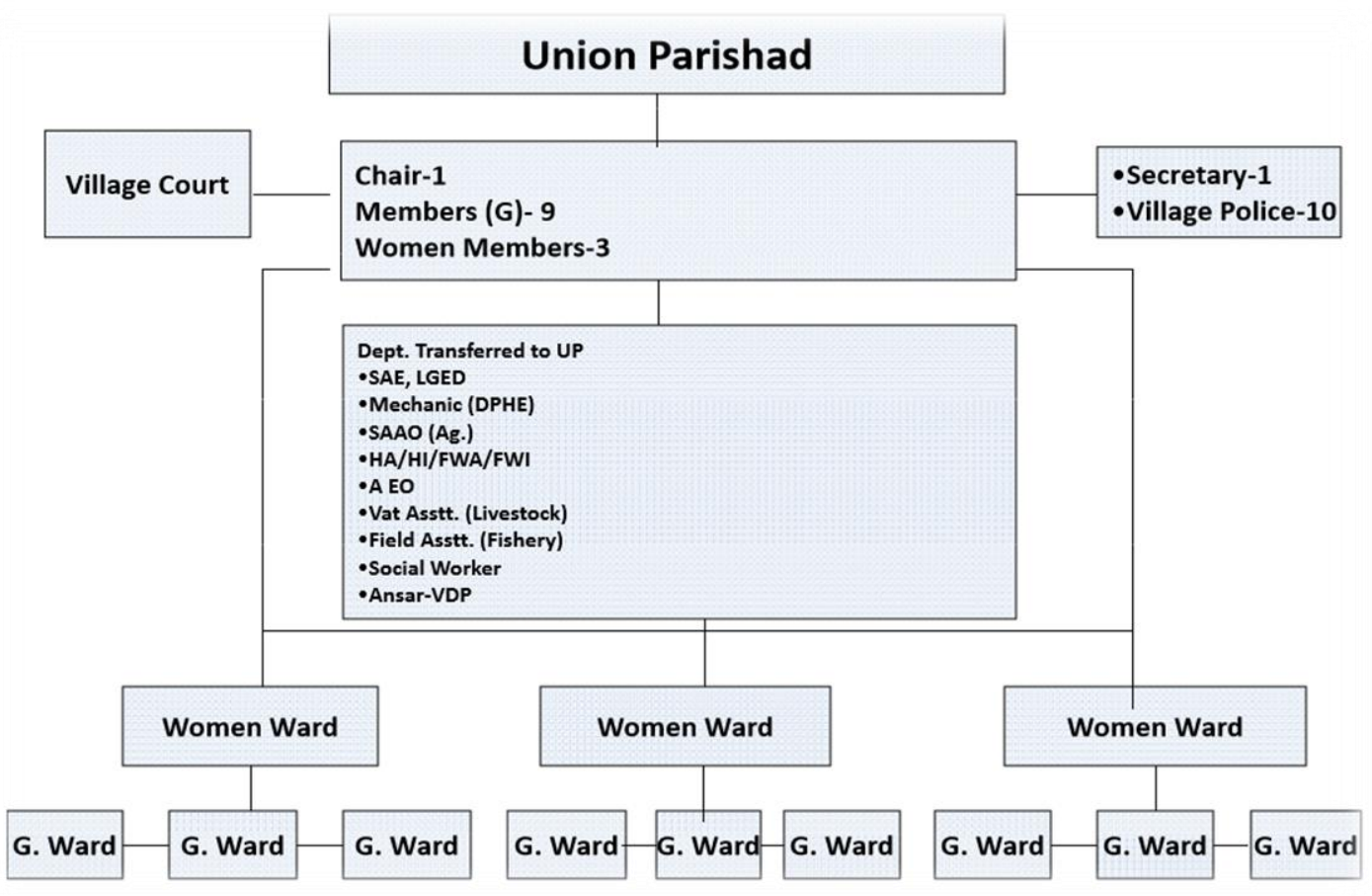

Figure 1. Structure of the Union Council in Bangladesh 


\subsection{Local Government Finance}

A World Bank working paper (Schaeffer and Yilmaz, 2008) on local government budgeting recognizes the fact that decentralization reforms in many developing countries are fostering changes in governance structures that are reshaping the relationship between local governments and citizens. The paper points out that the success of such decentralization reforms depends largely on the existence of sound public financial systems both at the central and local levels. Also, the role of budgeting is appreciated as a central tool in such reform efforts. It has also identified the problems or limitations that might hinder successful local government budget development and implementation.

To clarify this further, a UN-Habitat paper (UN Habitat, 2015) documents both the challenges and solutions related to the ability of local governments to mobilize revenues from local resources. An old edited book (Hye, 1985) deals with a similar issue in the context of decentralization of local government institutions in Bangladesh. Among others, a UN paper (United Nations, 2005) addresses the issues and challenges of local government participatory planning and budgeting process.

The editorial preface of a 1988 UNCRD book, written by Prantilla, E. B., identifies the fact that in many developing countries the core development problem at the sub-national level is the inadequate fiscal resource base of local and regional governments (Prantilla, 1988). Considering the bounded legal-rational framework of the local government, the same might be true in the case of Bangladesh, particularly at the Union Council level.

For instance, anecdotes and priori-observations support that in the case of geographical area of the study, there are plentiful local natural resources, while the problem is associated with the legal access barriers of local governments to those properties. Certainly, national-local tax base system of the country is a fundamental issue. In the case of Bangladesh, the nation's de jure practice is that tax from the major local sources goes to national government, and the same tax shall then be distributed at the national and sub-national level. Therefore, the local government tax net as well as base seems to be very poor in Bangladesh.

There is always a strong mismatch between the resources legitimately at hand of decentralized local governments in Bangladesh, like Union Councils, and the responsibilities assigned to them. It goes with Devas (1988) which fairly identifies the fact that the main reason for allocating national funds to local governments relates to the mismatch between the resources available to decentralized agencies and the responsibilities assigned to local governments.

A 2010 report of United Cities and Local Governments, published in 2011, further justifies "why local government finance is so important." The potential importance of local government finance is based on two main pillars. The core rationale is that local governments are well positioned to improve how public resources are used and the extent to which diverse citizen needs are satisfied. The second justification is the role that local governments could potentially play in dealing with several significant contemporary global challenges that broadly, although differentially, affect virtually all countries (United Cities of Local Government, 2011).

Nonetheless, Devas (1988) points out the debate on the issue as is presented below:

The allocation of national financial resources to decentralized authorities is hotly debated issue in most countries of the world. It involves the sharing of scarce resources, and with that, the issue of the power to control expenditure decisions in important areas of the public sector. The way in which these allocations are handled varies widely between countries and has generally evolved over many years within political, institutional and economic settings. Thus, generalizations can be misleading, and experiences cannot easily be transferred from one country to another (Devas In Prantilla ed. 1988).

Finally, the book on local government economics and finance edited by David King is one of the classic contributions. In the introduction of the book, Pola and King (1992), reveal that all the countries of western Europe have some form of democratic local government, and thus these countries are supposed to consider together the appropriate role for their local authorities and how these authorities should be financed. In the case of Bangladesh as well, now all forms of local governments are democratically elected.

Thoni (1992) deals with the lens of 'political economy' instead of purely 'economic' approach to tackle the local expenditure and frame the tax base. When it comes to the lens of political economy, it allows the analysis of the relationship between the institutional arrangements and the economic policies of the state and local authorities. In this context, analyzing the 'politics of local governments' refers to studying the decision-making processes of the local governments in relation to the politics of the local governments as well as the national government.

\subsection{Political Psychology and Applied Economics in Public Budgeting Decisions}

Individual level decision making is an area of research under the domain of cognitive psychology. Decision-making is simply regarded as the reasoning process resulting in the selection of a choice or deciding without choice options, or a 
course of action among several alternative possibilities. Several factors, including experience (Jullisson, Karlsson and Garling, 2005), cognitive biases (Stanovich and West, 2008), age and individual differences (Bruin, Parker and Fischhoff, 2007), belief in personal relevance (Acevedo and Krueger, 2004), and an escalation of commitment (Dietrich, 2010) influence individuals in their decision-making process.

Political psychology, however, is an interdisciplinary academic field related to describing how individuals as public institutional representatives make their decisions relating to budgeting considering the exogenous political and cognitive psychological factors, and thus it is dedicated to understanding politics, politicians and political behavior from a psychological perspective.

According to Cottam et al. (2010), political psychology intends to understand inter-dependent relationships between individuals and contexts that are influenced by beliefs, perception, cognition, motivation, socialization, information processing, learning strategies and attitude formation.

The way Henley (1992) defines budgeting, it strongly reveals the concept of applied economics. Within the study of public budgeting decision making, for instance, local government budgeting decision making invites applied economics in terms of allocating public resources, in addition to the political psychological process being practiced in public budgeting decisions as discussed above.

Budgeting is a process of measuring and converting plans for the use of real (i.e. physical) resources into financial values. It is the classic problem of how to add together quantities of apples and oranges into a meaningful economic measurement, the only practical way for everyday use is to express their economic values in terms of monetary costs and revenues. Through the process of budgeting the finance function provides the essential link between management planning and management control (Henley, 1992).

To understand the settings in the context of local government budgeting in Bangladesh and many other developing and even developed countries, we need to comprehend an old but classic literature review on 'system analysis' (Kramer, 1979:2) that focuses on economic rationality (i.e. the applied economics in this context). This system analysis refers to a blended approach of a set of concerns, such as community or social priorities, opportunity cost and risk analysis, results on investment including economic and non-economic returns, and appropriate level of expenditures and revenues.

\subsection{Concepts of Influence, Autonomy, De Jure and De Facto}

One hand, the term 'influence' refers here to the phenomenal capacity of an aspect to affect the budgeting decision or behavior of Union Councils. It denotes the capacity of influencer or the influencing aspect (i.e. persons or things) to tailor a compelling force on the action, choice and behavior relating to the budgeting decision of Union Councils in Bangladesh.

On the other hand, the concept of 'autonomy' simply makes sense here as the combination of degree of freedom, discretion of legal authority and level of rational power regarding the actions and decisions of the Union Councils in Bangladesh, particularly the budgeting decisions that they take in this context. Autonomy is an important property for self-government.

In this research, 'freedom' refers to Swift's view regarding effective freedom and freedom as autonomy (Swift, 2014: 66), as well as Kant's view that freedom consists in acting morally (Swift, 2014: 69). Also, 'legal authority', in this study, entails formal authority provided in the concerned laws/acts, policy documents, rules, and regulations whereas rational power implies the ability to exercise the given freedom and authority in a sensible manner.

The term 'de jure' refers here to the influencing facts or aspects in the budgeting decisions of Union Councils of Bangladesh that have strong legal basis whereas 'de facto' refers to the aspects or facts in those same decisions that arise from reality following economic, socio-political and social organizational practices rather than their legal basis.

In the case of the Union Council/Parishad (UP), some of the decisions are subject to be so routine that they can be made without risk consequences and alternatives being considered, whereas budgeting decisions are subject to be made by Union Councils in a way that is consistent with the local government principles in the context of Bangladesh as set out in the Local Government (Union Parishad) Act, 2009 (GOB, 2009), and other relevant rules and regulations. However, this is just a de jure aspect.

There might be other aspects/issues that could influence budgeting decisions of UPs in Bangladesh. Exploring these de jure and de facto issues, as well as understanding the relative influences of those issues on budgeting decisions of local government Union councils, is the central undertaking of this research. The study also reveals the fact whether the influencing issues collide with the budgetary autonomy of Union Councils. 


\subsection{Budget Theory}

According to Menifield (2013), budget comes in three forms: i) Line item, ii) Program, and iii) Performance. There are also budgeting techniques: a) Zero-based budgeting, and b) Incremental budgeting. In the case of zero-based budgeting, it starts from zero or beginning, and thus each unit submitting a budget must justify all their budget requests from beginning to end, while in incremental budgeting, an agency may also use an incremental approach to budgeting where it simply adds or subtracts from the previous year's spending. National governments may require agencies or local governments to submit a certain type of budget that they prefer (Axelrod, 1995; Gianakis and McCue, 1999; Menifield, 2013; Smith and Lynch, 2004; Thuurmaier and Willoughby, 2001).

Budgeting theories, especially Charles E. Lindblom's incrementalism in public decision making and Aaron Wildavsky's budgetary incrementalism, Irene Rubin's review of descriptive and normative budgetary theories and historical review of the budgetary reform process, and Wehner's critical analysis to Wildavsky's budgetary theory are likely to help much in analyzing the budgetary process and decisions with regards to understanding the ownership as well as accountability and the magnitude of budgetary autonomy of Union Councils in Bangladesh.

Wehner (2015) analyses Aaron Wildavsky's seminal work, The Politics of the Budgetary Process, published in 1964. Wehner considers Wildavsky's contribution as a classic one in public administration as the book used a simple yet fundamental theoretical framework for analyzing budgetary decisions that took an in-depth look at the norms and rules of budgeting in the United States and the stable patterns of interaction between the various actors involved. Wehner, however, discusses the challenges to Wildavsky's theory of budgetary incrementalism that arose mainly in the context of economic and fiscal crisis.

Following Wildavsky's 1964 contribution, Richard Fenno's successful book The Power of the Purse: Appropriations Politics in Congress, was published in 1966. Rubin (1990) attributes the fact that together Wildavsky and Richard Fenno framed the incrementalistic assumptions about budgeting at the national level: centrality of a legislatively dominated budget, the importance of agencies in the process, the decentralization of the process.

Rubin (1990) further observed the fact that the incrementalistic model argued that no major changes were made in the budgets from year to year and hence few choices of policy consequence were being made in the context of the budget. It, however, had lack of comparison between alternatives for spending, and prevented many budgeters from seeing the changing budget reality and theorizing about it.

Interestingly, Wildavsky gave up the framework that he had sketched in his 1964 book, and wrote a new book, The New Politics of the Budgetary Process, published in 1988. Also, it is notable the fact that incrementalism was originally built as a theory of public policy making in the 1950s by the American political scientist Charles E. Lindblom. In 1959, Lindblom wrote an easy The Science of Muddling Through, to help policymakers understand why they needed to consider a middle way between the 'rational actor model' and 'bounded rationality' to avoid making policy changes dramatically when they really get engaged to the complexity and evolving rationality of the issue.

'Incrementalism', a dominant theory in public budgeting, was intended not only to be a descriptive one but also to act as a normative theory. However, in the purely normative lens of public budgeting theory, public accountability, citizenry involvement and central-local partnership, transparency, cost-effectiveness, and quality service delivery are central to the literature. Rubin (1990) observes that these could only be achieved by improving the quality of budget information and publicizing that information to allow increased access of the people to such information.

Rubin (1990) further points out that both the public and legislature should understand the government's activities and achievements, and spending in those same areas. Thus, cost accounting, program budgeting implications and detailed performance budgets based on unit costs get reform attention, and this approach does not limit new services to be included in the budget considering the changing reality of the budget. Such reformers also emphasize the role of planning in the budget and argue that budgets must contain a work plan and provide funding for future as well as current needs.

\subsection{Budgeting Process}

The core process of budget preparation supposes to include setting up the fiscal targets given the compatible expenditure assignments and strategic allocation of resources and mechanism for ensuring aggregate expenditure control, operational efficiency and competitive advantages. Following the theoretical base, government policies as well as rules-regulations, and analyzing the trade-off as well as making prioritization from alternative options, setting up the most cost-effective variants supposes to be a sensible way for ensuring competitive advantage of the budgeting process. Figure-2 shows the world view of the budget cycle at a glance. 


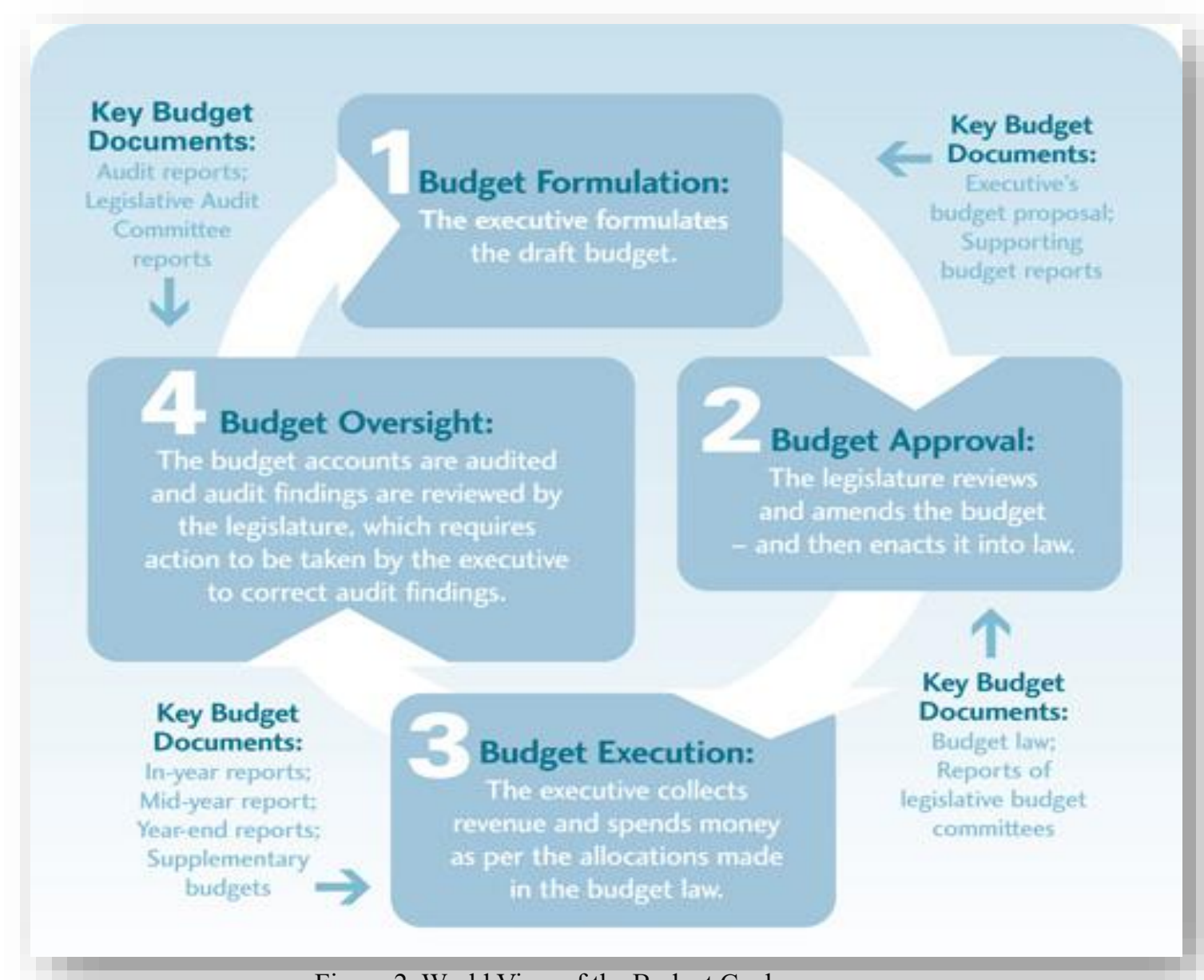

Figure 2. World View of the Budget Cycle

Source: Jay Colburn, International Budget Partnership ${ }^{4}$

Now understanding the process by which Union Councils in Bangladesh make budgeting decisions is important to explain the decisions they make in this regard. Figure-3 shows the budget life cycle of Union Councils in Bangladesh.

4 https://www.internationalbudget.org/2017/02/making-budget-cycle-budget-formulation-stage. Retrieved on March 12, 2018. 


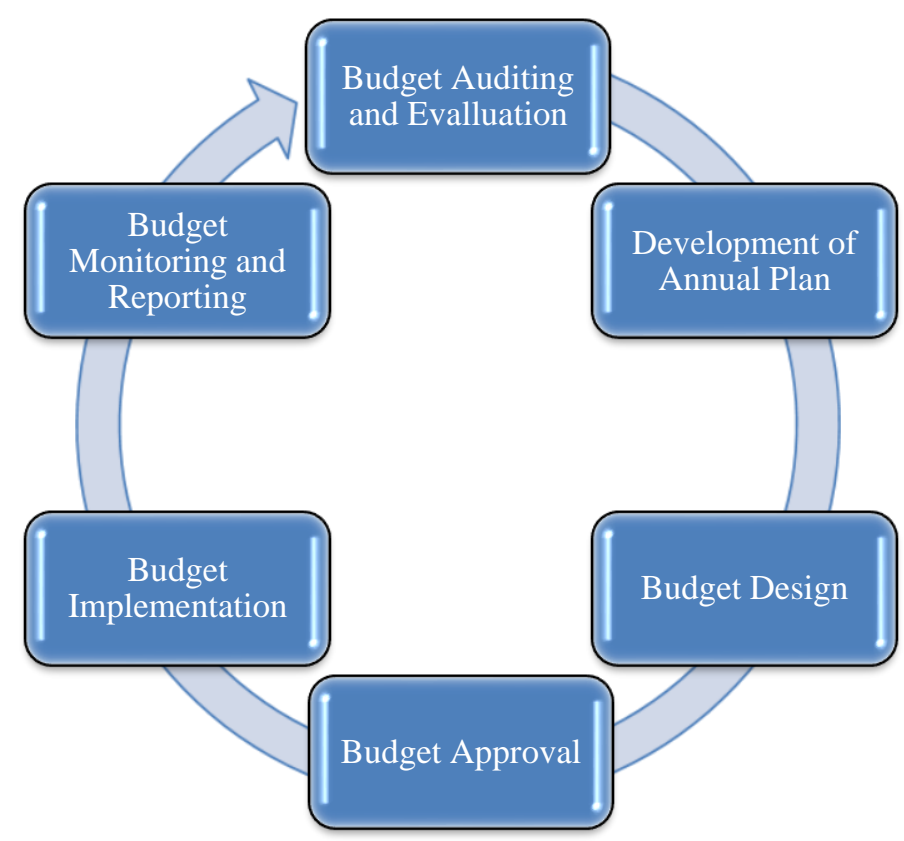

Figure 3. Budget Life Cycle of Union Councils

Source: Adapted from the Local Governance Programme Sharique's training documents

Budgeting process of a UP in Bangladesh supposes to start with tailoring an annual development plan by a planning committee, based on the strategic five-year plan of the UP. It requires reviewing the strategic five-year plan to sketch a draft plan, initiating ward $^{5}$ level discussions and placing ward level findings and demands to the UP-standing committees for their screening, making recommendations, and then framing the plan. ${ }^{6}$

Then usually the secretary along with the planning committee of a UP outlines the budget by subsuming the assessment of assets and revenues including grants, and assuming liabilities and expenditures based on the plan and office memos as well as documents, followed by placing the same to the Union Council Coordination Committee (UDCC) for its comments and conducting an open budget meeting by the UP Chair in the presence of hundreds of local citizens at the UP level. Usually the Chair of a UP presents the draft budget to the open budget meeting for public review and feedback. $^{7}$

Following public disclosure and assessment, the Union Council/Parishad revisits the budget and endorses it with or without making changes. UP then submits it to the delegated government authorities, i.e. Upazila Nirbahi Officer (UNO), Deputy Director of Local Government (DDLG) and Deputy Secretary (DC). Local Government Division (LGD) of the Ministry of Local Government, Rural Development and Cooperatives (MLGRD\&C) then allocates the actual amount of grants and keeps the UP informed through official letter. Thus, a UP again revisits the actual fund situation, revises and adjusts the budget, and re-endorses it. Next stage is the implementation followed by monitoring and reporting, as well as auditing and evaluation of the budget. ${ }^{8}$

\section{Research Results}

Identifying the exploratory variables, i.e. UP-budgeting decision aspects or de jure and de facto issues that could influence the outcome category variable (i.e. budgetary autonomy of Union Councils) is central to this research. Also, understanding the relative influences of the exploring categorical issues at UP budgeting process is imperative here. The research results have also satisfied the concern whether the influences of influencing issues collide with the autonomy of Union Councils in their budgeting decisions. Exploring the magnitude of budgetary autonomy of UPs is, however, beyond the terms of reference for this research article.

\footnotetext{
${ }^{5}$ There are nine subunits of a UP, each of which is known as a Ward.

${ }^{6}$ Based on the Local Governance Programme Sharique's UP budgeting training documents.

${ }^{7}$ Ibid

${ }^{8}$ Ibid
} 


\subsection{Influencing Factors}

4.1.1 What Are the Key Factors That Influence the Budgeting Decision-Making Process of the Union Councils/Parishads(UPs) in Their Local Governance?

Among the six cases of Union Councils/Parishads (UPs), Jamalgonj Sadar Union Council experiences the fact that the source of resources (i.e. amonut of local revenue, intergovernmental transfers and private as well as other nongovernmental direct development assistance), the previous year budget, and the political affiliation of the UP Chair, and education as well as leadership ability of the UP-Chair have a great influence on the UP-budgeting process and decisions. According to Fenarbak Union Council, the most likely influence factors in the UP budgeting process and decisions are sources of resources, the previous year budget (i.e. difference between the preliminary budget and the revised budget of the previous year), diversity, magnitude as well as priority of local demands, political affiliation of the UP Chair, and personal traits of the Chair (i.e. leadership, trained or untrained and education level).

Joysree Union Council opines its experience concerning the influence factors in its budgeting process and decisions in the following sequence: source of resources, scarcity of the resources as well as limited scope of local revenue generation, political affiliation of the UP Chair, previous year budget, diversity as well as magnitude of local problems, and education level of the Chair. Madhanagar Union Council views its experience in this regard in the following sequence: source of resources, previous year budget, scarcity of the resources, political affiliation of the UP Chair, government law, rules and regulations, collaboration, management and coordination aspects of the Union Council, education level as well as leadership ability of the Chair, and aptitude level and scope of capacity building for the council.

Sukhair Rajapur Union Council shares its experience with regards to the aspects of influence in its budgeting process and decisions in the following sequence: previous year budget, source of resources, scarcity of resources as well as limited local revenue scope, education level of the Chair as well as training opportunity for the council, political affiliation of the Chair, diversity as well as magnitude of local problems and conflicts of individual demands. Bhimkhali Union Council's experience in this regard reveals the following sequence: source of resources, previous year budget (i.e. amount of previous year revised budget and its deficit/surplus amount), resource gap (i.e. demand-supply gap) as well as poor amount of local revenue, area-based diversity as well as magnitude of problems along with individual stakeholder's influence, political affiliation of the Chair, and education level as well as leadership ability of the Chair and competence of the council. The synopsis of the aspects or issues that influence the UP-budgeting decision-making process is documented in Box1.

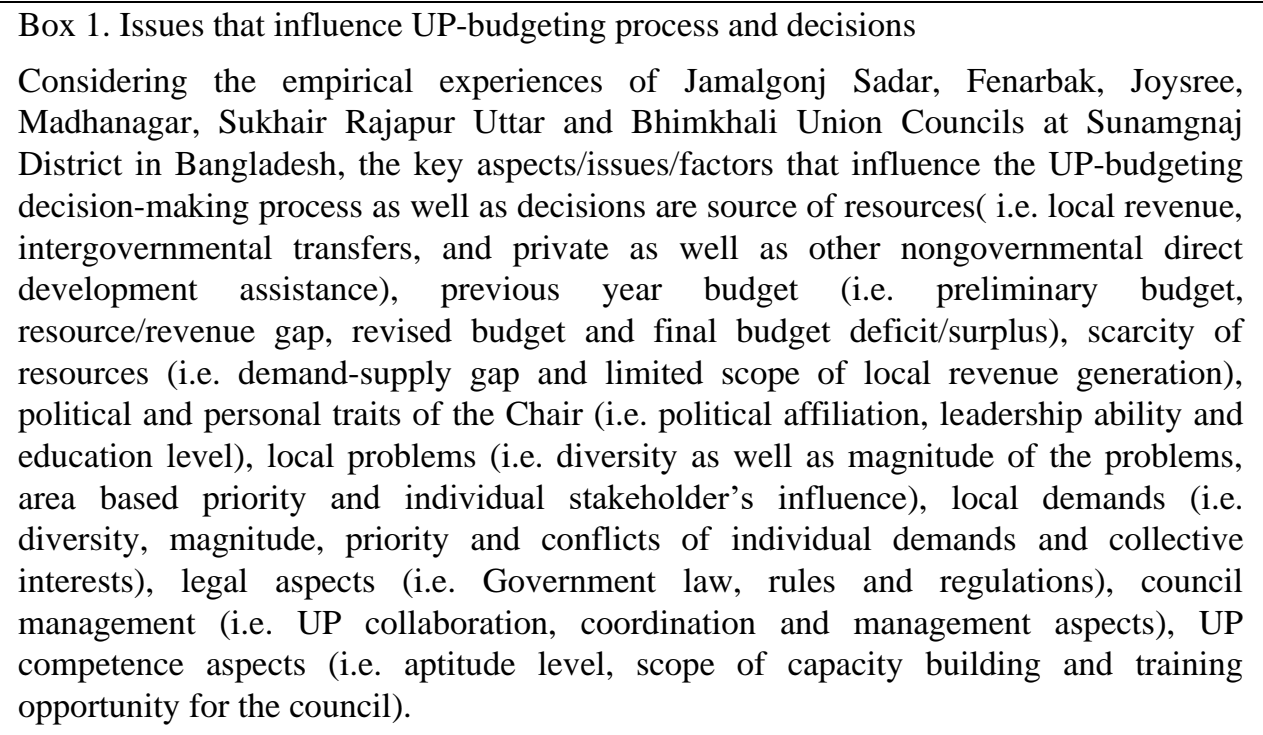

\subsubsection{What Are the De Facto and De Jure Issues That Could Influence the UP-Budgeting Decision-Making Process?}

Almost all the aspects of influence in the UP-budgeting decision-making process could have been both de jure and de facto characters. Following the in-depth discussions with six case-UP Chairs, and FGDs with UP Chairs, Councilors and Secretaries, Table-2 below reveals how these aspects of influence could have entailed de jure and de facto notions and characters. 
Table 2. De jure and de facto features of the aspects of influence in UP-budgeting decisions

\begin{tabular}{l}
\hline Aspects of influence \\
\hline Source of resources (i.e. \\
local revenue, \\
inter-governmental \\
transfers, and private as \\
well as other \\
non-governmental direct \\
development assistance) \\
Previous year budget \\
(i.e. preliminary budget, \\
resource/revenue gap, \\
revised budget and final \\
budget deficit/surplus)
\end{tabular}

Scarcity of resources (i.e. demand-supply gap and limited scope of local revenue generation)

Political and personal traits of the Chair (i.e. political affiliation, leadership ability and education level)

Local problems (i.e. diversity as well as magnitude of the problems, area-based priority and individual stakeholder's influence)

Local demands (i.e. diversity, magnitude, priority and conflicts of individual demands and collective interests)

Legal aspects (i.e. government law, rules and regulations)

Council management

(i.e. UP collaboration,

coordination and

management aspects)

UP competence aspects (i.e. aptitude level, scope of capacity building and training opportunity for the council).
De jure features

Source of resources holds de jure feature in a sense that acquisition of own revenue of UPs, inter-governmental transfers and private and/or other non-governmental transfers to UPs have legal basis.

Previous year budget works as a point of reference for incrementalism, a dominant theory in public budgeting. It intends not only to be a descriptive, but also to act as a normative theory.

UPs have neither enough tax base nor sufficient local resource entitlement. As such UPs heavily depend on inter-governmental transfer as well as non-governmental support.

There is no de jure ground for political and personal traits of UP Chairs, except they must be elected by the electorate or citizens of the community.

Legal basis is grounded on the local public management authority of UPs (i.e. decentralization and local governance)

Legal basis is grounded on the local public management authority of UPs (i.e. decentralization and local governance)

Fully fledged de jure aspects

Legal basis is grounded on the organization (i.e. local government unit - UP)

There is no vibrant point of legal reference for building up competence of UPs.
De facto features

It is de facto in a sense that UPs are unenthusiastic to collect the maximum level of local revenue because even though maximum amounts of local revenues get collected, such amounts would be very insignificant compared to the aggregate budget sizes of these local revenues.

In practice it works as a point of reference for incrementalism only in understanding the previous year's initial budget amount and actual resource gained as well as the year end deficit/surplus based on that revised budget. In fact, it entails a combination of political psychology, applied economics and local public problems, demands, priorities, and organization and management issues.

In practice, UPs get insufficient inter-governmental and rarely non-governmental support compared to the increasing local demands for public goods and services.

All political and personal traits of the Chairs hold de facto aspects of influence.

De facto features are inbuilt here with conflicts of interests of the UP Chair and councilors, and influential stakeholders including concerned legislator's unjustified influences.

De facto features are inbuilt here with conflicts of interests of the UP Chair and councilors, and influential stakeholders including concerned legislator's unjustified influences.

Not applicable

UP collaboration, coordination and management practices always do not have rational basis, and as such these entail, to a certain extent, de facto features.

Any initiative for training-transfer and building up the competence of a UP, aiming to get a competitive advantage for the council, seems to be a de facto practice to date.

\subsection{Relative Influences}

\subsubsection{What Are the Relative Influences of Aspects/Issues in the UP-Budgeting Decision-Making Process?}

The scale of score (1-9, where 9 ranks the highest and 1 represents the lowest) is set by the researcher, but the weight of the score against each influencing issue is marked by the six classified sample UPs at Sunamganj District in Bangladesh following the second-round discussions with six case-UP Chairs and Secretaries. The relative influence of the aspects/issues in UP-budgeting decision-making process depends on the case and the situation. Therefore, the weight of the influencing aspects slightly varies among sample UPs. Table-3 shows the score difference and weighted average scores of the influences or influencing aspects in UP-budgeting decision-making process. 
Table 3. Weighted average scores of the aspects influencing the UP-budgeting decisions

\begin{tabular}{lcccccccc}
\hline & \multicolumn{3}{c}{ JamalgonjFenar } & \multicolumn{7}{c}{ Joysree Madha } & \multicolumn{3}{c}{ RajapurBhim Total } & Aver \\
& Sadar & Bak & & Nagar & Uttar & Khali & \\
\hline Source of resources & 9 & 9 & 9 & 9 & 8 & 9 & 53 & $\mathbf{8 . 8}$ \\
Previous year budget & 8 & 8 & 8 & 8 & 9 & 8 & 49 & $\mathbf{8 . 2}$ \\
Scarcity of resources & 6 & 7 & 9 & 8 & 8 & 8 & 46 & $\mathbf{7 . 7}$ \\
$\begin{array}{l}\text { Political \& personal } \\
\text { traits of the Chair }\end{array}$ & 7 & 7 & 8 & 7 & 7 & 6 & 42 & $\mathbf{7}$ \\
Local problems & 7 & 7 & 7 & 7 & 7 & 7 & 42 & $\mathbf{7}$ \\
Local demands & 7 & 9 & 7 & 7 & 6 & 7 & 43 & $\mathbf{7 . 2}$ \\
Legal aspects & 7 & 6 & 6 & 7 & 6 & 6 & 38 & $\mathbf{6 . 3}$ \\
Council management & 5 & 5 & 5 & 7 & 7 & 5 & 34 & $\mathbf{5 . 7}$ \\
UP competence & 5 & 6 & 6 & 7 & 7 & 7 & 38 & $\mathbf{6 . 3}$ \\
\hline
\end{tabular}

Considering the average scores out of 9 in Table-3, source of resources (i.e. local revenue, inter-governmental transfers, and private as well as other non-governmental direct development assistance) gets the highest average score of 8.8, the previous year budget (i.e. preliminary budget, resource/revenue gap, revised budget and final budget deficit/surplus) ranks second with an average score of 8.2, scarcity of resources (i.e. demand-supply gap and limited scope of local revenue generation) positions third with an average score of 7.7.

Furthermore, local demands (i.e. diversity, magnitude, priority and conflicts of individual demands and collective interests) positions fourth with an average score of 7.2, political and personal traits of the Chair (i.e. political affiliation, leadership ability and education level) and local problems (i.e. diversity as well as magnitude of the problems, area-based priority and individual stakeholder's influence) jointly rank fifth with an average score of 7, legal aspects (i.e. government laws, rules and regulations) and UP competence aspects (i.e. aptitude level, scope of capacity building and training opportunity for the council) jointly rank sixth with an average score of 6.3, and council management (i.e. UP collaboration, coordination and management aspects) stands last with an average score of 5.7. Figure-4 below portrays the relative influences of the abovementioned factors or issues in the UP-budgeting decision-making process and decisions.

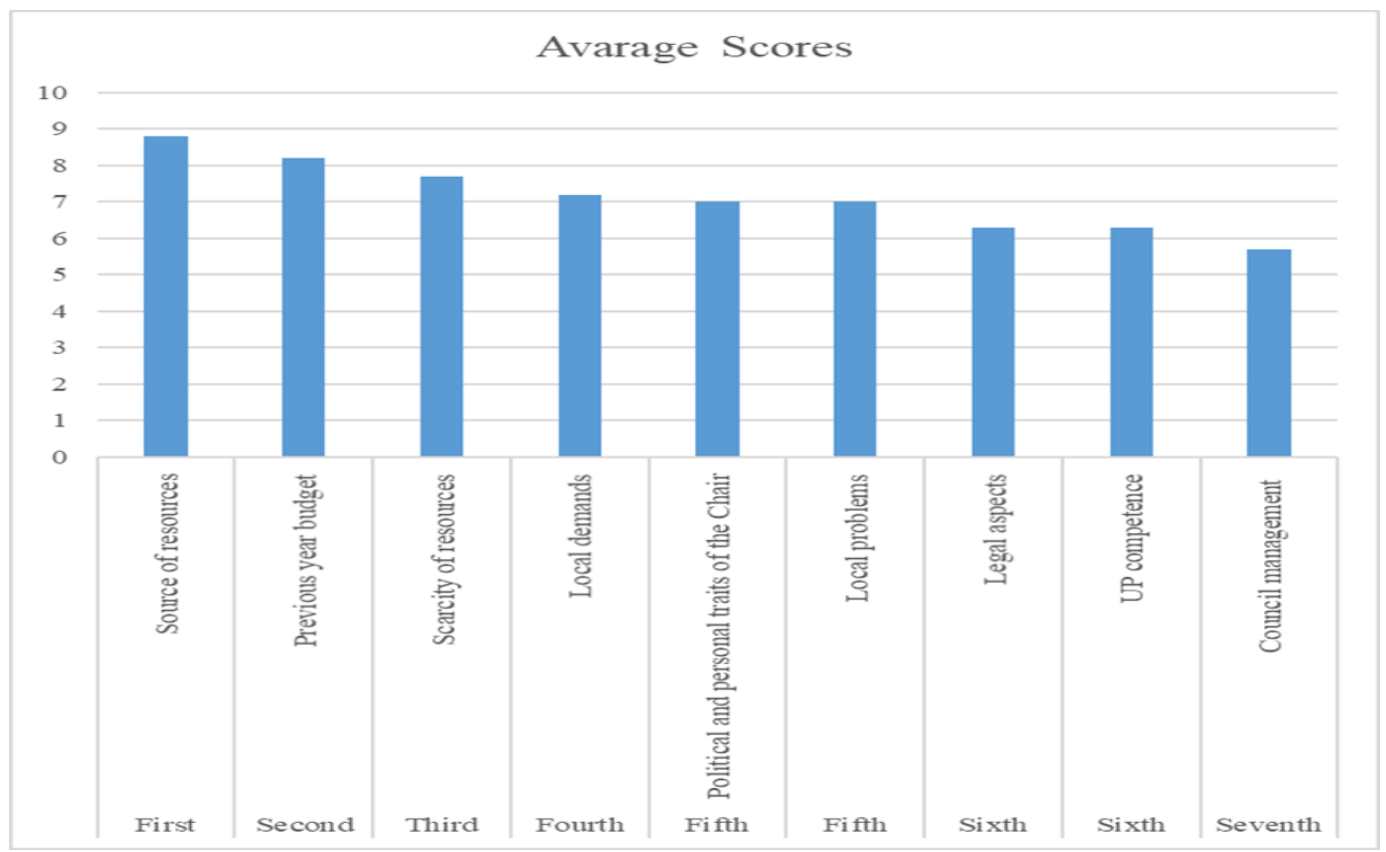

Figure 4. Relative influences of the aspects in UP-budgeting decisions 


\subsubsection{Do the Influences Collide With the Autonomy of the Union Councils in Their Budgeting Decisions?}

Discussions with UP representatives, field notes and previous participant-observations ${ }^{9}$ simply reveal that influence of aspects/issues in UP-budgeting decision-making process does not certainly or always collide with the autonomy of UPs in their budgeting decisions, but the effects of stated aspects are evident with varying degrees and dimensions on the budgeting decisions as well as budgetary autonomy of UPs, even to the wider context of UP management and local governance.

\section{Contributions of the Study}

The contribution of the study is revealing the critical influencing phenomena and their relative influences in UP-budgeting decisions. Such contribution is tailor-made based on the grounded theory data-analytic principles (Glaser, 1978). The contribution of this research has two streams: theoretical and practical.

\subsection{Theoretical Contribution}

\subsubsection{Critical Influencing Phenomena}

Almost all of the influencing phenomena - source of resources, previous year budget, scarcity of resources, local demands, political and personal traits of the Chair, local problems, legal aspects, UP competence aspects, and council management - holds both de jure and de facto characters, except political and personal traits of UP Chairs, and legal aspects. There is no de jure ground for political and personal traits of UP Chairs, excluding the fact that they must be elected by the electorate of the community, while legal aspects hold entirely a de-jure nature.

\subsubsection{Influencing Phenomena and the Budgetary Autonomy}

Influence of concerned phenomena does not necessarily collide with the budgetary autonomy of UPs, but the effects of the influencing issues on the UP-budgeting decisions are evident with varying degrees and dimensions.

\subsection{Practical Contribution}

\subsubsection{Context Specific Relative Influences of the Influencing Phenomena}

Sources as well as scarcity of resources and previous year budget are extremely influential in UP governance and development, especially in its budgeting process and decisions in the context of Sunamganj District in Bangladesh. Among other influences, local problems as well as demands (including diversity as well as magnitude of the problems, area-based priority, conflicts between individual demands and collective interests, and individual stakeholder's influence, for example, MP and local ruling party politicians' influence), political and personal traits of the Chair as well as UP competence and legal aspects (i.e. government law, rules and regulations, and their dominations) and council management (including collaboration and coordination within the council and with the standing committees, project implementation committees, planning committee and union development coordination committee and community stakeholders) have significant influence in UP-budgeting process and decisions, and the beyond - UP overall management and local governance.

\section{Conclusion}

As the local government planning as well as budgeting is centrally positioned in the discussion of subnational level of decentralization, especially in its fiscal as well as political decentralization, the literature, results and subsequent theoretical as well as practical contributions of this research have provided significant input in the study of public administration and management, and public budget theories.

The research has explored the critical phenomena that influence UP budgeting process, and revealed their magnitude of influences in UP budgeting decisions. The discussion on the findings and analysis gratifies the research concerns by identifying the exploratory variables (i.e. UP-budgeting decision aspects/phenomena) that could influence in the outcome category variable (i.e. autonomy in the budgeting decisions of Union Councils).

Research has found that influence of concerned phenomena in UP-budgetary process does not certainly/always collide with the autonomy of UPs in their budgeting decisions, but the effects of such aspects/ phenomena are evident with varying degrees and dimensions on the budgetary autonomy of local government Union Councils in Bangladesh.

\footnotetext{
${ }^{9}$ The researcher had previous participant-observations on the issue being a former board member of the local governance programme sharique that operated at Sunamganj, Rashahaji, Chapai Nawabganj and Khulna Districts at Union Council/Parishad level. The project closed in June 2017.
} 
The validation of the latter one requires supplementary study to understand the causal mechanism and the process of influences, as well as to reveal the magnitude of budgetary autonomy of Union Councils in Bangladesh. Notably, Talukdar (2019) is one of such supplemental studies.

\section{Acknowledgement}

This is one of the articles developed based on my Ph.D. research. I acknowledge the review and guidance contribution of the Ph.D. advisors Dr. Achakorn Wongpreedee, Associate Professor of Graduate School of Public Administration (GSPA)-National Institute of Development Administration (NIDA), and Dr. Tatchalerm Sudhipongpracha, Associate Professor of Thammasat University. I also admit the extensive contribution of the Ph.D. dissertation seminar instructor Dr. Boon-Anan Phinaitrup, Associate Professor and Dean of GSPA-NIDA, Bangkok. I highly appreciate the contribution of the Social Science Research Council, Planning Division, Ministry of Planning, Government of the People's Republic of Bangladesh, in my PhD research leading to this publication.

\section{Appendix A}

Population, sampling, and basic data of sample Ups

Population and sampling

\begin{tabular}{lll}
\hline Aspects & Design & Remarks \\
\hline & The population for this & The research has executed at one District under one \\
& study consists of 87 Union & Division/Region out of eight Regions in Bangladesh, \\
Population & Councils/Parishads (UPs) at & considering the manageability of the qualitative data \\
& Sunamganj District/Zila in & collection. \\
& Sylhet region of Bangladesh.
\end{tabular}

A list of 87 Union The criteria based purposively selected samples are Sampling Councils/Parishads (UPs) of picked from the population and sampling frame by frame total 11 Sub-districts/Upazilas at Sunamganj District/Zila under the Sylhet Division/ using some parameters given the priori data from Local Governance Programme Sharique. Region in Bangladesh.

\begin{tabular}{|c|c|c|}
\hline Sample size & $\begin{array}{l}\text { Sample size is } 6 \text { (Union } \\
\text { Councils/Parishads), and } \\
\text { these are purposively selected } \\
\text { based on the criteria, set in } \\
\text { the remarks to the right of this } \\
\text { row. }\end{array}$ & $\begin{array}{l}\text { Based on the aggregate budget size as well as the } \\
\text { amount of intergovernmental transfer (with high and } \\
\text { low amounts); and private/nongovernmental direct } \\
\text { development assistance (with high and low amounts); } \\
\text { based on the own/local revenue scopes as well as } \\
\text { collection (with high and low amounts); based on the } \\
\text { political affiliation of the UP Chairs (affiliated with the } \\
\text { political party in power, and from a strong opposition } \\
\text { party). Data require for } 3 \text { fiscal years - 2014-15, } \\
2015-16 \text { and 2016-17. Data collection period: } \\
\text { January-February 2018. }\end{array}$ \\
\hline
\end{tabular}

List of sample Union Councils

\section{SUNAMGANJ DISTRICT/ZILA IN BANGLADESH}

Dharmapasha Subdistrict/Upazila

- Joysree Union Council

- Uttar Sukhair Rajapur Union Council

- Madhanagar Union Council
Jamalganj Subdistrict/Upazila

- Jamalganj Sadar Union Council

- Bhimkhali Union Council

- Fenarbak Union Council 


\section{Appendix B}

Structure and Feature of the Union Council in Bangladesh

\begin{tabular}{|c|c|c|c|c|c|c|}
\hline $\begin{array}{l}\text { Level } \\
\& \\
\text { Quantity }\end{array}$ & $\begin{array}{l}\text { Area } \\
\& \\
\text { Populati } \\
\text { on Per } \\
\text { Unit } \\
\end{array}$ & $\begin{array}{l}\text { Legal } \\
\text { Basis }\end{array}$ & $\begin{array}{l}\text { Headed } \\
\text { By }\end{array}$ & Composition & $\begin{array}{l}\text { Revenue } \\
\text { Authority }\end{array}$ & $\begin{array}{l}\text { Functional } \\
\text { Observation }\end{array}$ \\
\hline $\begin{array}{l}4553 \\
\text { Lowest unit } \\
- \\
\text { Exclusively } \\
\text { Rural }\end{array}$ & $\begin{array}{l}26.18 \\
(\mathrm{~km}) 2 \\
27,000\end{array}$ & $\begin{array}{l}\text { The Local } \\
\text { Governme } \\
\text { nt (Union } \\
\text { Parishad) } \\
\text { Act, } 2009 \\
\text { (Act No. } \\
61 \quad \text { of } \\
2009)\end{array}$ & $\begin{array}{l}\text { Elected } \\
\text { Chairman }\end{array}$ & $\begin{array}{l}\text { A Union } \\
\text { Parishad } \\
\text { consists of } 1 \\
\text { elected } \\
\text { Chairman and } \\
12 \text { members } \\
\text { including } \\
\text { members } \\
\text { exclusively } \\
\text { reserved for } \\
\text { women. There } \\
\text { is also a } \\
\text { secretary to the } \\
\text { Parishad. }\end{array}$ & $\begin{array}{l}\text { Limited } \\
\text { revenue } \\
\text { authority } \\
\text { and scope } \\
\text { are there, but } \\
\text { it does not } \\
\text { have } \\
\text { sub-national } \\
\text { borrowing } \\
\text { authority. }\end{array}$ & $\begin{array}{l}\text { Participatory } \\
\text { planning and } \\
\text { budgeting, and } \\
\text { implementation, } \\
\text { as well as } \\
\text { service } \\
\text { monitoring } \\
\text { powers are } \\
\text { there, but its } \\
\text { staffing capacity } \\
\text { is limited. }\end{array}$ \\
\hline
\end{tabular}

Source: Based on Talukdar, 2013

\section{References}

Acevedo, M., \& Krueger, J. (2004). Two egocentric sources of the decision to vote: The voter's illusion and the belief in personal relevance. Political Psychology, 25(1), 115-134. https://doi.org/10.1111/j.1467-9221.2004.00359.x

Ahmed, T. (2014). Findings Overview for LGSP-II in Jessore, Nilphamari and Satkhira. Manusher Jonno Foundation, CARTA Program. Dhaka.

Ahmed, T. (2015). Review of the Book titled "Local Governance in Bangladesh - Policy and Strategy Framework" authored by Talukdar, MRI 2014. Commonwealth Journal of Local Governance, 18. http://epress.lib.uts.edu.au/journals/index.php/cjlg/article/view/4852/5218

Axelrod, D. (1995). Budgeting for Modern Government, Second Edition. New York: St. Marin's Press, Inc.

Baker, E., Kan, M., \& Teo, S. T. T. (2011). Developing a collaborative network organization: leadership challenges at multiple levels. Journal of Organizational Change Management, 24(6), 853-875. https://doi.org/10.1108/09534811111175797

Bruin, W.B., Parker, A.M., \& Fischhoff, B. (2007). Individual differences in adult decision-making competence. Journal of Personality and Social Psychology, 92(5), 938-956. https://doi.org/10.1037/0022-3514.92.5.938

Coston, J. (1998). Administrative Avenues to Democratic Governance: The Balance of Supply and Demand. Public Administration and Development, 18(5), 479-493. https://doi.org/10.1002/(SICI)1099-162X(199812)18:5<479::AID-PAD37>3.0.CO;2-Y

Cottam, M. L., Dietz-Uhler, B., Mastors, E., \& Preston, T. (2010). Introduction To Political Psychology (2nd ed.). New York, NY: Psychology Press.

Dauda, C. L. (2006). Democracy and Decentralization: Local Politics, Marginalization and Political Accountability in Uganda and South Africa. Public Administration and Development, 26, 291-302. https://doi.org/10.1002/pad.411

Devas, N. (1988). 'System of Allocation of Government Funds to Local and Regional Governments' In Prantilla, E. B. (ed.) Financing Local and Regional Development in Developing Countries: Selected Country Experiences. Nagoya: UNCRD.

Dietrich, C. (2010). Decision Making: Factors that Influence Decision Making, Heuristics Used, and Decision Outcomes. Inquiries Journal, 2(2).

Eckardt, S. (2008). Political accountability, fiscal conditions and local government performance - cross- sectional evidence from Indonesia. Public Administration and Development, 28, 1-17. https://doi.org/10.1002/pad.475 
Falguni, A. (2009, December 18). Review of the Book titled "Rural Local Government in Bangladesh" authored by Talukdar, MRI 2009. The Daily Star. http://www.thedailystar.net/news-detail-118255

Fenno, R. (1966). The Power of the Purse: Appropriations Politics in Congress.

Gianakis, G. A., \& McCue, C. P. (1999). Local Government Budgeting. A Managerial Approach. West Port, CT: Praeger.

Glaser, B. (1978). Theoretical Sensitivity. Mill Valley, CA: Sociology Press.

GOB. (2009). The Local Government (Union Parishad) Act 2009. Local Government Division: Dhaka.

Grindle, M. S. (2007). Going Local: Decentralization, Democratization, and the Promise of Good Governance. Princeton, NJ.: Princeton University Press.

Henley, D. (1992). Public Sector Accounting and Financial Control, 4th ed, London and New York: Chapman \& Hall.

Hicks, J. F., \& Kaminski B. (1995). Local Government Reform and Transition from Communism: The case of Poland. Journal of Developing Societies, 9(1), 1-20.

Hodgson. G. (2006). What are Institutions? Journal of Economic Issues, 40(1), 1-25. https://doi.org/10.1080/00213624.2006.11506879

Hye, H. A. (1985). Decentralization, local government institutions and resource mobilization. International seminar proceedings, Comilla: BARD.

Jullisson, E. A., Karlsson, N., \& Garling, T. (2005). Weighing the past and the future in decision making. European Journal of Cognitive Psychology, 17(4), 561-575. https://doi.org/10.1080/09541440440000159

Klingner, D. E. (1996). Public Personnel Management and Democratization: A View from Three Central American Republics. Public Administration Review, 56(4), 390-399. https://doi.org/10.2307/976381

Kramer, F. A. (1979). 'Traditional Simplification Versus Systematic Analysis' In Kramer. Fred. A. (ed.). Contemporary Approaches to Public Budgeting. Winthrop Publixhers, Inc: Cambridge.

Lindblom, C. E. (1959). The Science of Muddling Through. https://doi.org/10.2307/973677

McGill, R. (1997). Civil service Reform in Developing Countries: A strategic Perspective from an Institutional Development Base. International Journal of Public Sector Management, 10(4), 254-267. https://doi.org/10.1108/09513559710180529

Menifield, C. E. (2013). The Basics of Public Budgeting and Financial Management, Second Edition. Lanham, Boulder, New York, Toronto and Polymouth: University Press of America.

Organization for Economic Co-operation and Development (OECD). (1996). Ethics in the Public Service Current Issues and Practices. Paris: OECD.

Oxhorn, P. (2004). Unraveling the Potential of Decentralization. In Oxhorn,P., Tulchin, JS and Selee, A. (eds.) Decentralization, Democratic Governance, and Civil Society in Comparative Perspective: : Africa, Asia, and Latin America, Pennsylvania Ave. NW: Woodrow Wilson Center Press with Johns Hopkins University Press.

Pola, G., \& King, D. (1992). 'Introduction' In King (ed.) Local Government Economics in Theory and Practice. London and New York: Routledge.

Prantilla, E. B. (1988). Financing Local and Regional Development in Developing Countries: Selected Country Experiences. Nagoya: UNCRD.

Rainey, H. G. (1997). Understanding and Managing Public Organizations. San Francisco: Jossey-Bass.

Rubin, I. S. (1990). Budget Theory and Budget Practice: How Good the Fit? Public Administration Review, 50(2), 179. https://doi.org/10.2307/976865

Schaeffer, M., \& Yilmaz, S. (2008). Strengthening Local Government Budgeting and Accountability. Policy Research Working Paper 4767.World Bank, November 2008. https://doi.org/10.1596/1813-9450-4767

Smith, R. W., \& Lynch, T. D. (2004). Public Budgeting in America, Fifth Edition. Upper Saddle River, NJ: Pearson/Prentice Hall.

Smoke, P. (2003). Decentralization in Africa: Goals, Dimensions, Myths and Challenges. Public Administration and Development, 23(1), 7-16. https://doi.org/10.1002/pad.255

Stanovich, K. E., \& West, R. F. (2008). On the relative independence of thinking biases and cognitive ability. Journal of Personality and Social Psychology, 94(4), 672-695. https://doi.org/10.1037/0022-3514.94.4.672 
Swift, A. (2014). Political Philosophy, Third Edition. Cambridge and Malden: Polity Press.

Talukdar, M. R. I. (2013). Rural Local Government In Bangladesh. Second Edition. Dhaka: Osder Publications.

Talukdar, M. R. I. (2014). Local Governance in Bangladesh-Policy and Strategy Framework, Dhaka: Osder Publications.

Talukdar, M. R. I. (2019). Autonomy in Budgeting Decisions of Local Government Union Councils: A Study of Bangladesh. Journal of Pubic Administration and Governace, 9(2), 30-70. https://doi.org/10.5296/jpag.v9i2.14773

Thoni, E. (1992). 'The Political Economy of Tax and Expenditure' In King (ed.) Local Government Economics in Theory and Practice. London and New York: Routledge.

Thuurmaier, K. M., \& Willoughby, K. G. (2001). Policy and Politics in State Budgeting. Armonk, NY: M.E. Sharpe.

United Cities of Local Government, (2011). The Local Government Finance: The Challenges of the 21st Century. Cheltenham and Northampton: UCLG.

United Nations Human Settlements Programme. (2015). The Challenge of Local Government Financing in Developing Countries. Nairobi: UN-Habitat.

United Nations. (2005). Participatory Planning and Budgeting at the Sub-national Level. New York: UN.

USAID Center for Democracy and Governance. (2000). Decentralization and Democratic Local Governance Programming Handbook. Washington, D.C.

Wehner, J. (2015). Aaron Wildavsky, The Politics of the Budgetary Process. In M. et al. Lodge (Ed.), The Oxford Handbook of Classics in Public Policy and Administration. Oxford: Oxford University Press. https://doi.org/10.1093/oxfordhb/9780199646135.013.17

Wildavsky, A. (1964). The Politics of the Budgetary Process. Boston.

Wildavsky, A. (1988). The New Politics of the Budgetary Process.

\section{Copyrights}

Copyright for this article is retained by the author(s), with first publication rights granted to the journal.

This is an open-access article distributed under the terms and conditions of the Creative Commons Attribution license which permits unrestricted use, distribution, and reproduction in any medium, provided the original work is properly cited. 